\title{
Protein digestion and amino acid and peptide absorption
}

By D. B. A. Silk, G. K. Grimble and R. G. Rees, Department of Gastroenterology and Nutrition, Central Middlesex Hospital, London NW10 ${ }_{7} N S$

Although it has become clear that brush-border hydrolysis, and consequent utilization of the monosaccharide transport system, is the predominant method of absorption of the luminal products of carbohydrate digestion in man, it now appears certain that two major mechanisms are involved in the absorption of the luminal products of protein digestion: $(x)$ transport of liberated free amino acids by group specific active amino acid transport systems, and (2) uptake of unhydrolysed peptides by mechanisms independent of the specific amino acid entry mechanisms.

\section{Protein sources}

Exogenous protein. Dietary protein is deived from animal and vegetable sources and makes up $11-14 \%$ of the average energy intake. In Western diets this amounts to about 70-100 g protein/d.

Endogenous protein. Significant amounts of protein derived from endogenous sources such as gastric, biliary, pancreatic and intestinal secretions also require assimilation by the human gastrointestinal tract. Although the initial animal studies of Nasset and co-workers suggested that the endogenous pool was considerably larger than the exogenous pool (Nasset et al. 1955; Nasset \& Ju, I961), more recent studies performed in man indicate that the endogenous pool is approximately one-third the size of the exogenous protein pool (Nixon \& Mawer, I $970 a, b$; Johansson, 1975).

\section{Site of protein assimilation}

The bulk of ingested protein appears to be absorbed in the proximal jejunum (Borgstrom et al. 1957; Nixon \& Mawer, 1970a,b; Johansson, 1975; Silk et al. 1979). Small amounts reach the ileum and are absorbed at this site (Adibi \& Mercer, 1973; Silk et al. 1979; Chung et al. 1979a) and, as judged by the protein content of ileostomy effluent, absorption of protein is not completed in the small intestine (Gibson et al. 1976). The site of endogenous protein assimilation in man has not been characterized, but recent animal studies implicate the colon as the major site (Curtis et al. 1978).

\section{Luminal protein digestion}

The initial step in protein digestion is its denaturation at acid $\mathrm{pH}$ in the stomach by the action of several pepsins with varying substrate specificities (Taylor, 1968; Turner, 1968; Whitecross et al. 1973). Negligible amounts of free amino acids are 
released, and large polypeptides enter the duodenum to be hydrolysed further by pancreatic proteolytic enzymes.

The intraluminal digestion of proteins by pancreatic proteolytic enzymes has been reviewed in some detail by Gray \& Cooper (197I) and the zymogen enzymes, exopeptidases, by Keller ( 1968 ). Each of the proteolytic pancreatic enzymes is secreted as an inactive precursor (zymogen). For example, trypsinogen is activated by contact with enterokinase, an enzyme that has been isolated in a highly-purified form from the brush-border-membrane fraction of human intestinal mucosa (Lobley et al. 1973; Schmitz et al. 1973; Hermon-Taylor et al. 1977). Trypsin then hydrolyses bonds in the other zymogens to form the active enzymes.

In addition to pancreatic proteolytic enzymes, recent studies indicate the presence of solubilized intestinal brush-border and cytoplasmic intestinal mucosal amino oligopeptidases in intestinal contents (Josefsson \& Lindberg, 1967; Silk et al. 1976a). In the jejunum, these enzymes are unlikely to have a functionally significant role in the terminal stages of protein digestion. In the ileum the activity of luminal peptidases is higher so that here significant quantities of luminal peptides may be hydrolysed in the gut lumen rather than at the surface of ileal mucosal cells.

The products of luminal proteolysis are free amino acids and small peptides having a chain length of two to six amino acid residues (Chen et al. 1962; Nixon \& Mawer, 1970a,b; Adibi \& Mercer, 1973). Analysis of post-prandial intestinal contents aspirated from human jejunum reveals that approximately only one-third of the total amino acid content exists in the free form (Adibi \& Mercer, 1973). The nature of the oligopeptides in terms of distribution of chain-length frequency and amino acid composition has not yet been characterized.

\section{Free amino acid transport}

As with glucose transport, results of in vitro experiments have shown that active amino acid transport is dependent on a gradient of sodium ions across the brush-border membrane of intestinal epithelial cells (Schultz \& Curran, 1970). The absorptive patterns of free amino acids have been studied in some detail in man using various in vivo steady-state perfusion techniques. In these experiments saturation of transport was reached with increasing solute concentration compatible with the existence in man of carrier-mediated mechanisms for amino acid transport (Adibi \& Gray, 1967; Adibi et al. 1967; Adibi, 1969, 1970; Hellier et al. 1973). Also, different affinities of different free amino acids for these mechanisms were indicated by variations in the absorption rate of individual free amino acids when perfusion studies were performed with the use of equimolar mixtures of different acids (Adibi \& Gray, 1967; Adibi et al. 1967; Adibi, 1969). To date, the absolute $\mathrm{Na}$ dependency of free amino acid transport has not been demonstrated in vivo in man (Silk \& Dawson, 1979).

The results of competition studies in animals have indicated the likely existence of three major group-specific active transport systems (Matthews, 1971): (I) monoamino monocarboxylic (neutral amino acids), (2) dibasic amino acids and 
cystine, (3) dicarboxylic (acidic) amino acids. It should be borne in mind that the subject is complicated by species differences and by the fact that certain amino acids may be transported by more than one mechanism, e.g. glycine, proline and hydroxyproline. In man the in vitro and in vivo studies of amino acid transport in patients with Hartnup disease and cystinuria have firmly established the existence of mechanisms (I) and (2) (see reviews by Matthews, 1975; Matthews \& Adibi, 1976; Silk \& Dawson, 1979).

\section{Mucosal transport of peptides}

Initial experiments in vitro with dipeptides showed that small amounts of unhydrolysed glycyl-glycine and glycyl-L-leucine crossed the intestinal wall (Agar et al. I954). Similar observations were made when glycyl-glycine was studied in vitro (Wiggans \& Johnston, 1958, 1959) and in vivo (Newey \& Smyth, 1959). Newey \& Smyth (1960) demonstrated that dipeptides could be taken up intact by intestinal mucosa and concluded that the products of protein digestion could be transported into the mucosal cell in the form of oligopeptides as well as amino acids (Newey \& Smyth, 1962).

The concept of intact peptide uptake as a second mode of protein absorption, although not disputed, was not thought to be quantitatively significant, as it seemed much more likely that absorption of peptides, analogous to disaccharides, would involve brush-border hydrolysis with subsequent absorption of the released amino acids by amino acid transport systems.

The modern era of our knowledge of peptide absorption stems from the results of oral-load experiments, carried out by Matthews and his colleagues, in man (Craft $e t$ al. 1968). They found that a given quantity of glycine was absorbed faster when administered orally as the dipeptide or tripeptide than in the free form. It was concluded that the glycine peptides were transported unhydrolysed into the mucosal cell because, if hydrolysis had preceded uptake, then, at the best, the net rates of glycine transport from the free and peptide forms would have been the same.

\section{Evidence for intact transport of dipeptides in man}

Of all the experimental results available in favour of dipeptide transport in human intestine, the most persuasive is still derived from experiments performed in patients with Hartnup disease and cystinuria. In Hartnup disease there is an intestinal transport defect for free neutral amino acids and in cystinuria for dibasic amino acids and cystine (see Milne, 197I). Despite these transport defects the 'affected' amino acids have been shown to be absorbed normally or near normally when presented to the mucosa in the form of homologous or mixed dipeptides (Navab \& Asatoor, 1970; Asatoor et al. 1970a,b, 1972; Hellier et al. 1972b; Silk et al. 1975a). If any of the dipeptides administered to these patients had been hydrolysed to a substantial degree in the bulk phase of the gut lumen, or by brush-border peptidases before transport of released amino acids by specific 
active-transport processes, then absorption of the affected amino acids would not have occurred. This was clearly not the case in these experiments.

Additional evidence supporting the existence of intact dipeptide transport in human small intestine has included the following. Firstly, the competition between free amino acids for mucosal uptake is avoided or much reduced when solutions of dipeptides instead of corresponding free amino acid mixtures are instilled into the gut lumen (Adibi, 1971; Hellier et al. 1972a; Silk et al. 1973b; Silk, 1974). Similar observations, but on a wider scale, have been made in animal studies (Matthews, 1975). Secondly, in all the human dipeptide perfusions in vivo, faster rates of uptake of at least one of the constituent residues has been observed from dipeptide than from corresponding free amino acid solutions (Adibi, 197r; Cook, 1972; Hellier et al. 1972a; Silk et al. 1973b). This line of evidence is open to criticism because the same phenomenon has been observed in three perfusion studies with disaccharides (Cook, 1973; Fairclough et al. 1977; Sandle et al. 1977) which are thought to be hydrolysed at the brush-border and not to be transported intact. Nonetheless, unlike the sugar experiments, the kinetic advantage conferred by dipeptides on amino acid transport has been a consistent finding and of much greater magnitude. Finally, unhydrolysed glycyl-glycine has been detected in peripheral plasma samples during intestinal perfusion in vivo (Adibi, 1971), and in other studies carnosine, anserine and hydroxyproline peptides have also been detected in the peripheral circulation during oral-feeding experiments in man (Prockop \& Sjoerdsma, 196r; Prockop et al. 1962; Perry et al. 1967; Hueckel \& Rogers, 1970).

\section{Characteristics of dipeptide transport in man}

Matthews and co-workers have shown in vitro that intestinal transport of glycyl sarcosine and carnosine occurs via a carrier-mediated $\mathrm{Na}$-dependent process (Addison et al. 1972; Matthews et al. 1974). Doubt has subsequently been thrown on the $\mathrm{Na}$ dependency of peptide transport, because Rubino et al. (1971) have shown appreciable influx of peptides into rabbit ileal mucosa in vitro after $\mathrm{Na}$ replacement. Cheeseman \& Parsons (1974) have reported that transport of glycyl-leucine by the small intestine of Rana pipiens in vivo was unaffected by replacement of intralumen $\mathrm{Na}$ by potassium, whereas transport of glycine and leucine from the equivalent mixture of free amino acids was inhibited.

In man, saturation of transport of three dipeptides has been reached during perfusion in vivo of increasing solute concentrations (Adibi, 1971; Silk, 1977). Competitive inhibition between two dipeptides has been observed (Adibi \& Soleimanpur, 1974) which confirms the existence of a carrier-mediated dipeptide transport mechanism in human small intestine. The $\mathrm{Na}$ dependency of this transport process has not yet been investigated.

Free amino acids have not been shown substantially to alter the absorption rates of either glycyl-glycine or glycyl-leucine in vivo, which suggests that the carrier-mediated transport system for dipeptides in human small intestine is not shared by free amino acids (Adibi \& Soleimanpur, 1974). 
Appearance of free amino acids in the gut lumen during dipeptide perfusion

A consistent finding during in vivo dipeptide perfusion experiments in human small intestine is the detection of free amino acids in intestinal contents aspirated from the distal end of the perfusion segment (Adibi, r971; Cook, 1972; Hellier et al. $1972 a, b$; Silk et $a l$. 1973b, 1974b, 1975a). The rate of appearance of free amino acids during perfusion of different peptides varies (Adibi, 1971; Silk et al. $1973^{b}$ ) and substantially faster rates of appearance have been observed during ileal compared with jejunal dipeptide perfusion (Adibi, $197 \mathrm{I}$; Silk et al. 1974c).

Intraluminal peptidase activity is insufficient to account for the appearance of more than a small proportion of the released free amino acids (Adibi, 1971; Silk et al. $1973^{b}$ ) which implies that, analogous to disaccharide transport, a close relationship exists between the mucosal transport and hydrolysis of dipeptides. Numerous studies have now shown that there are two distinct groups of mucosal peptidases, one located within the cytoplasmic compartment and the other at the brush-border of the cell (for reviews, see Kim, I977; Noren et al. 1977). It seems very likely, therefore, that the appearance of free amino acids during dipeptide perfusion is related to hydrolysis of components of luminal peptide by brush-border peptidases, and that a proportion of the liberated free amino acids diffuse back into the bulk phase of the gut lumen (Silk, I974; Matthews, 1975; Matthews \& Adibi, 1976). Animal studies support this view, as the rate of appearance of free amino acids during absorption of two dipeptides was related to the differential activity of the brush-border rather than cytoplasmic peptidases obtained from intestinal mucosa at the end of the experiments (Silk et al. 1976b).

\section{Models of dipeptide transport and hydrolysis}

At first sight a scheme proposing that dipeptides are transported intact and hydrolysed by cytoplasmic peptidases would appear to explain most of the experimental results, especially the findings of normal transport of dipeptides in the face of transport defects for free amino acids in Hartnup disease and cystinuria. Nevertheless, the appearance of free amino acids during dipeptide transport has been a consistent finding. As mentioned previously, this is likely to be related to brush-border hydrolysis. We believe therefore (Silk, 1974; Silk \& Dawson, 1979) that a dual hypothesis for peptide transport is applicable. Thus on the one hand, those peptides with a high affinity for brush-border peptidases are predominantly hydrolysed by these enzymes and absorbed as free amino acids, whereas those with low affinities for the surface enzymes are absorbed predominantly intact.

\section{Tripeptide absorption in man}

Absorption of three tripeptides has been investigated in man (Craft et al. 1968; Silk et al. 1974b; Adibi et al. 1975). During in vivo intestinal perfusion studies (Silk et al. I974b; Adibi et al. 1975), the rate of amino acid uptake has been shown to be significantly greater from tripeptide than from corresponding free amino acid solutions. Whether this is indicative of intact transport of tripeptide or of 
constituent dipeptide released following brush-border hydrolysis is not entirely clear. In all these experiments, constituent free and dipeptide bound amino acids were released into the lumen during tripeptide perfusion. As with dipeptides, the relative rates of appearance of hydrolysis products varied according to the chemical structure of tripeptide perfused. Subfractionation studies using human intestine reveal approximately equal distributions of tripeptidase activity between brush-border and soluble fractions (Nicholson \& Peters, 1977a,b), so it seems reasonable to conclude that substantial proportions of at least two of the infused tripeptides, alanyl-glycyl-glycine and trileucine, were hydrolysed at the brush-border before uptake of constituent dipeptide and amino acid by a peptide and a free amino acid transport mechanism respectively. As with dipeptides, a dual mechanism for the intestinal handling of tripeptides may be proposed as the available results indicate that substantially greater proportions of triglycine were absorbed intact. Again, the quantitative importance of the brush-border hydrolysis $v$. intact transport mechanisms is likely to be dictated by the affinity of the tripeptide substrate for the brush-border peptidases.

\section{Tetrapeptide transport in man}

The absorption of only one tetrapeptide, tetraglycine, has been studied in human intestine in vivo (Adibi \& Morse, 1977). No evidence of intact absorption was found, and hydrolysis of the peptide at the brush-border appears to be the rate-limiting step in absorption.

The results of animal studies are more conflicting for, although evidence has been presented in one in vivo study to suggest that significant components of L-leucyl-triglycine may be absorbed intact and subsequently hydrolysed by cytoplasmic peptide hydrolases (Chung et al. 1979b), all the other available findings (Burston et al. 1979; Smithson \& Gray, 1977) suggest that brush-border hydrolysis plays a pivotal role in tetrapeptide assimilation, and that tetrapeptides, like higher peptides, require brush-border hydrolysis before absorption of the liberated amino acids, and di- and tripeptides by the mechanisms described previously.

\section{Nutritional importance of peptide transport}

The studies carried out in Hartnup disease and cystinuria have emphasized the nutritional importance of oligopeptide transport in these two conditions. The recently-described kinetic advantage conferred by individual peptides on the intestinal assimilation of amino acid residues has been a consistent finding in most experiments and has suggested the possibility that there could be nutritional implications of peptide transport in normal human subjects.

As there are 400 possible dipeptides and 8000 possible tripeptides it clearly has been impossible to assess the overall nutritional importance of peptide transport by studying the absorption characteristics of each in turn. As an alternative means of investigating the problems, native proteins have been hydrolysed by enzymic methods under controlled in vitro conditions to yield final mixtures consisting predominantly of oligopeptides, with smaller quantities of free amino acids. 
Equivalent free amino acid mixtures whose composition and molar pattern simulated those of the partial enzymic hydrolysates of protein have also been prepared, and comparisons made in man of the extent of absorption of amino acid residues from the partial enzymic hydrolysates of whole protein and their respective equivalent free amino acid mixtures using a steady-state in vivo perfusion technique.

Initial experiments were performed using two hydrolysates of casein and one each of fish protein and lactalbumin (Silk et al. 1973a, 1975b, 1980). Several consistent features of the experiments emerged. The first related to the extreme variability that occurred in the extent of absorption of amino acid residues from the free amino acid mixtures. This variability in amino acid uptake was not nearly so marked, however, during intestinal perfusion of the four protein hydrolysates. The reason for this was that many of the amino acid residues that were absorbed poorly from the free amino acid mixtures were absorbed to a significantly greater extent from the protein hydrolysates. Finally, with the exception of the studies with the fish-protein hydrolysate (Fairclough et al. 1980), total absorption of $a$-amino acid-nitrogen was greater during perfusion of the protein hydrolysates than from the equivalent free amino acid mixtures (Silk et al. I973a, I975 b, I980).

Intestinal perfusion studies have shown that the kinetic advantage conferred by peptides on the rates of amino acid transport is maintained even when the absorptive function of intestinal mucosa is reduced as, for example, in untreated adult coeliac disease (Adibi et al. 1974; Silk et al. 1974a). There is, moreover, experimental evidence from animal studies suggesting that long-term protein restriction causes a decrease in the absorption of free amino acids but not peptides (Lis et al. 1972). In the light of these findings, and taking into consideration also the possibility that the more 'even' uptake of amino acid residues from partial enzymic hydrolysates of whole protein (as compared with that from free amino acids) has a beneficial effect on protein synthesis (Payne \& Matthews, 1975), we believe that there could be advantages in using such partial hydrolysates rather than free amino acids as the $N$ source in 'chemically-defined elemental' enteral diets (Silk, 1980). These diets have a preferred use in the nutritional management of patients with severely-impaired gastrointestinal function.

Although the use of a peptide rather than free amino acid $\mathrm{N}$ source in these diets may confer better taste properties on the diet, and reduce the osmotic load (osmolality $\times$ rate of infusion) administered during enteral nutrition, there are, as yet, no convincing results showing any significant nutritional advantage in terms of protein turnover. Studies designed to investigate this aspect of protein metabolism are currently in progress in our unit.

Persuing our belief that there could be advantages to using a peptide-based $\mathrm{N}$ source in predigested elemental diets, we could provide no simple explanation as to why considerable variations were noted in the pattern of amino acid residue uptake from the four protein hydrolysates first tested (Silk et al. I980). It seemed to us that a number of factors could influence the pattern of amino acid uptake from these preparations, and that these could include differences in the amino acid 
composition and sequencing of the different native proteins, the variability of the hydrolysis methods used to produce the protein hydrolysates and, also, differences that might have existed in the chain-lengths of the constituent peptides in the hydrolysates.

In subsequent studies (Keohane et al. 1981) we have shown that both the type of starter protein and hydrolysis method influence absorptive properties in the human small intestine. In the first of two studies designed to investigate the influence of peptide chain-length, substantially faster absorption was observed from a low-molecular-weight (MW) lactalbumin hydrolysate containing peptides with a predominant chain-length of two to five residues than from a higher-MW lactalbumin hydrolysate containing peptides with a predominant chain-length of ten to fifteen residues (P. P. Keohane, G. K. Grimble, B. Higgins, M. Kaminski and D. B. A. Silk, unpublished results). Our most recent work (Rees et al. 1984), an extention of the latter experiments, has further shown that significantly faster absorption occurred from two ovalbumin hydrolysates containing a predominance of di- and tripeptides than from a third that contained a predominance of tetraand pentapeptides. Under the conditions of our perfusion technique in which pancreatic enzyme activity is excluded, it would seem that maximum rates of absorption occur from protein hydrolysates when they contain peptides that are capable of being absorbed intact in the unhydrolysed form (i.e. di- and tripeptides). Brush-border peptide hydrolysis plays a pivotal role in the assimilation of tetra-, penta- and higher peptides (Smithson \& Gray, 1977), so our latest studies (Rees et al. 1984) strongly suggest that brush-border peptide hydrolysis is the major factor that limits the rate of intestinal uptake of amino acid residues from partial enzymic hydrolysates of whole protein. If maximal absorption of amino acid-N is required in clinical situations where there is severe impairment of gastrointestinal function, consideration could be given not only to using a peptide rather than free-amino-acid-based $\mathrm{N}$ source, but an $\mathrm{N}$ source composed predominantly of diand tripeptides rather than the wide spectrum of peptides present in most of today's commercially-available predigested and chemically-defined elemental diets.

\section{REFERENCES}

Addison, J. M., Burston, D. \& Matthews, D. M. (1972). Clinical Science 43, 907-911.

Adibi, S. A. (1969). Gastroenterology 56, 903-91 3.

Adibi, S. A. (1970). Fournal of Applied Physiology 28, 753-757.

Adibi, S. A. (1971). Fournal of Clinical Investigation 50, 2266-2275.

Adibi, S. A., Fogel, M. R. \& Agrawal, R. M. (1974). Gastroenterology 67, 586-591.

Adibi, S. A. \& Gray, S. J. (1967). Gastroenterology 52, 837-845.

Adibi, S. A., Gray S. J. \& Menden, E. (1967). American Fournal of Clinical Nutrition 20, 24-33.

Adibi, S. A. \& Mercer, D. W. (1973). Journal of Clinical Investigation 52, I 586-I 594.

Adibi, S. A. \& Morse, E. L. (1977). Fournal of Clinical Investigation 60, 1008-1016.

Adibi, S. A., Morse, E., Masilamani, S. \& Amin, P. (1975). fournal of Clinical Investigation 56, $1355^{-1} 3^{6} 3$.

Adibi, S. A. \& Soleimanpur, M. R. (1974). Fournal of Clinical Investigation 53, 1368-1374.

Agar, W. T., Hird, F. J. R. \& Sidhu, G. S. (1954). Biochimica et Biophysica Acta 14, 80-84.

Asatoor, A. M., Bandoli, J. K., Lant, A. F., Milne, M. D. \& Navab, F. (r970a). Gut II, 250-254.

Asatoor, A. M., Cheng, B., Edwards, K. D. G., Lant, A. F., Matthews, D. M., Milne, M. D., Navab, F. \& Richards, A. J. (1970b). Gut II, 380-387. 
Asatoor, A. M., Harrison, B. D. W., Milne, M. D. \& Prosser, D. I. (1972). Gut 13, 95-98.

Borgstrom, D., Dahlquist, A., Lundh, G. \& Sjovall, J. (1957). fournal of Clinical Investigation 36, $1521-1536$.

Burston, D., Taylor, E. \& Matthews, D. M. (1979). Biochimica et Biophysica Acta 553, $175^{-1} 78$.

Cheeseman, C. I. \& Parsons, D. S. (1974). Biochimica et Biophysica Acta 363, 523-526.

Chen, M. L., Rogers, Q. R. \& Harper, A. G. (1962). Journal of Nutrition 76, 235-24I.

Chung, Y. C., Kim, Y. S., Shadchehr, A., Garrido, A., MacGregor, I. L. \& Sleisinger, M. H. (1979a). Gastroenterology 76, $1415^{-1} 4^{21}$.

Chung, Y. C., Silk, D. B. A. \& Kim, Y. S. (1979b). Clinical Science 57, 1-11.

Cook, G. C. (1972). Clinical Science 43, 443-453.

Cook, G. C. (1973). Clinical Science 44, 425-428.

Craft, I. L., Geddes, D., Hyde, C. W., Wise, I. J. \& Matthews, D. M. (1968). Gut 9, 425-437.

Curtis, K. J., Kim, Y. C., Perdoma, J. M., Silk, D. B. A. \& Whitehead, J. S. (1978). fournal of Physiology 274, 409-4I 9 .

Fairclough, P. D. (1978). The effects of amino acids, peptides and saccharides. MD Thesis, University of London.

Fairclough, P. D., Hegarty, J. E., Silk, D. B. A. \& Clark, M. L. (1980). Gut 21, 829-834.

Fairclough, P. D., Silk, D. B. A., Webb, J. P. W., Clark, M. L. \& Dawson, A. M. (1977). Clinical Science and Molecular Medicine 53, $24 \mathrm{I}-248$.

Gibson, J. A., Sladen, G. E. \& Dawson, A. M. (1976). British fournal of Nutrition 35, 61-65.

Gray, G. M. \& Cooper, H. L. (1971). Gastroenterology 61, 535-544.

Hellier, M. D., Holdsworth, C. D., McColl, I. \& Perrett, D. (1972a). Gut 13, 965-969.

Hellier, M. D., Holdsworth, C. D., \& Perrett, D. (1973). Gastroenterology 65, 61 3-618.

Hellier, M. D., Holdsworth, C. D., Perrett, D. \& Thirumalai, C. (1972b). Clinical Science 43, $659-668$.

Hermon-Taylor, J., Perrin, J., Grant, D. A. W., Appleyard, A., Bubel, M. \& Magee, A. I. (1977). Gut 18, 259-265.

Hueckel, H. J. \& Rogers, Q. R. (1970). Comparative Biochemistry and Physiology 32, 7-16.

Johansson, C. (1975). Scandinavian fournal of Gastroenterology 10, 33-42.

Josefsson, L. \& Lindberg, T. (1967). Acta Chemica Scandinavica 21, 1965-1966.

Keller, P. J. (1968). In Handbook of Physiology, vol. 5, pp. 2605-2628 [C. F. Code, editor]. Washington, DC: American Physiological Society.

Keohane, P. P., Brown, B., Grimble, G. K. \& Silk, D. B. A. (1981). Fournal of Parenteral and Enteral Nutrition 5, 568.

Kim, Y. S. (1 977). Ciba Foundation Symposium 50 (New Series), 1 59-1 76.

Lis, M. T., Crampton, R. F. \& Matthews, D. M. (1972). British Yournal of Nutrition 27, I 59-167.

Lobley, R. W., Moss, S. \& Holmes, R. (1973). Gut $\mathbf{1}_{4}, 8$ i 7 .

Matthews, D. M. (1971). Fournal of Clinical Pathology 5 (Suppl. 14), 29-40.

Matthews, D. M. (1 975). Physiological Reviews 55, 537-608.

Matthews, D. M., Addison, J. M. \& Burston, D. (1974). Clinical Science and Molecular Medicine 46, 693-705.

Matthews, D. M. \& Adibi, S. A. (1976). Gastroenterology 71, 151-161.

Matthews, D. M., Gandy, R. H., Taylor, E. \& Burston, D. (1979). Clinical Science 56, I 5-23.

Milne, M. D. (1971). Yournal of Clinical Pathology 5 (Suppl. Roy. Coll. Path.), 4I-44.

Nasset, E. S. \& Ju, J. S. (196r). Fournal of Nutrition 74, $461-465$.

Nasset, E. S., Schwartz, P. \& Weiss, H. V. (1955). Fournal of Nutrition 56, 83-94.

Navab, F. \& Asatoor, A. M. (1970). Gut 11, 373-379.

Newey, H. \& Smyth, D. H. (1959). Fournal of Physiology, London 145, 48-56.

Newey, H. \& Smyth, D. H. (1960). Journal of Physiology, London 152, 367-380.

Newey, H. \& Smyth, D. H. (1962). Fournal of Physiology, London 164, 527-55I.

Nicholson, J. A. \& Peters, T. J. (1977a). Clinical Science and Molecular Medicine 52, I6P.

Nicholson, J. A. \& Peters, T. J. (1977b). Gut 18, A960-A961.

Nixon, S. E. \& Mawer, G. E. (1970a). British Yournal of Nutrition 24, 227-240.

Nixon, S. E. \& Mawer, G. E. (1970b). British fournal of Nutrition 24, 241-258.

Noren, O., Sjostrom, H., Svensson, B., Jeppesen, L., Staun, M. \& Josefsson, L. (1977). Ciba Foundation Symposium 5o (New Series), $177-198$.

Payne, J. W. \& Matthews, D. M. (1975). In Peptide Transport in Protein Nutrition, pp. $1-60$ [D. M. Matthews and J. W. Payne, editors]. Amsterdam: Associated Scientific Publishers. 
Perry, T. L., Hansen, S., Tischler, B., Bunting, R. \& Berry, K. (1967). New England Journal of Medicine 277, $1219-1227$.

Prockop, D. J., Keiser, H. R. \& Sjoerdsma, A. (1962). Lancet ii, 527-528.

Prockop, D. J. \& Sjoerdsma, A. (1961). Yournal of Clinical Investigation 40, 843-849.

Rees, R. G., Grimble, G. K., Keohane, P. P., Higgins, B., West, M., Spiller, R. C. \& Silk, D. B. A. (1984). Gut 25, A547.

Rubino, A., Fields, M. \& Shwachman, H. (1971). Fournal of Biological Chemistry 246, $354^{2}-35^{88}$.

Sandle, G. I., Lobley, R. W. \& Holmes, R. (1977). Gut 18, A944.

Schmitz, J., Preiser, H., Maestracci, D., Ghosh, B. K., Cerda, J. J. \& Crane, R. K. (1973). Biochimica et Biophysica Acta 323, 98-1 12.

Schultz, S. G. \& Curran, P. F. (1970). Physiological Reviews 50, 637-718.

Silk, D. B. A. (1974). Gut $\times 5,494-501$.

Silk, D. B. A. (1977). Ciba Foundation Symposium 50 (New Series), 15-26.

Silk, D. B. A. (1980). Proceedings of the Nutrition Society 39, 61-70.

Silk, D. B. A., Chung, Y. C., Berger, K. L., Beigler, M., Sleisinger, M. H., Spiller, G. A. \& Kim, Y.C. (1979). Gut 20, 29 1-299.

Silk, D. B. A., Clark, M. L., Marrs, T. C., Addison, J. M., Burston. D., Matthews, D. M. \& Clegg, K. M. (1975a). British Fournal of Nutrition 33, 95-100.

Silk, D. B. A. \& Dawson, A. M. (1979). In International Review of Physiology. Gastrointestal Physiology III, vol. 19, pp. $151-204$ [R. K. Crane, editor]. Baltimore: University Park Press.

Silk, D. B. A., Fairclough, P. D., Clark, M. L., Hegarty, J. E., Marks, T. C., Addison, J. M., Burston, D., Clegg, K. M. \& Matthews, D. M. (1980). Journal of Parenteral and Enteral Nutrition $4,54^{8-553}$.

Silk, D. B. A., Kumar, P. J., Perrett, D., Clark, M. L. \& Dawson, A. M. (1974a). Gut 15, 1-8.

Silk, D. B. A., Marrs, T. C., Addison. J. M., Burston, D., Clark, M. L. \& Matthews, D. M. (1973a). Clinical Science and Molecular Medicine 45, 715-719.

Silk, D. B. A., Nicholson, J. A. \& Kim, Y. S. (1976a). American Fournal of Physiology 23x, 1322-1329.

Silk, D. B. A., Nicholson, J. A. \& Kim, Y. S. $(1976 b)$. Gut $17,870-876$.

Silk, D. B. A., Perrett, D. \& Clark, M. L. (1973b). Clinical Science and Molecular Medicine 45, 29I-299.

Silk, D. B. A., Perrett, D. \& Clark, M. L. (1975b). Gastroenterology 68, 1426-1432.

Silk, D. B. A., Perrett, D., Webb, J. P. W. \& Clark, M. L. (1974b). Clinical Science and Molecular Medicine 46, 393-402.

Silk, D. B. A., Webb, J. P. W., Lane, A. E., Clark, M. L. \& Dawson, A. M. (1974C). Gut Is, 444-449.

Smithson, K. W. \& Gray, G. M. (1977). Journal of Clinical Investigation 60, 665-674.

Taylor, W. H. (1968). In Handbook of Physiology, vol. 5, pp. 2567-2587 [C. F. Code, editor]. Washington, DC: American Physiological Society.

Turnes, M. D. (1968). Gut 9, 134-138.

Whitecross, D. P., Armstrong, C., Clarke, A. D. \& Piper, D. W. (1973). Gut 14, 850-855.

Wiggans, D. S. \& Johnston, J. M. (1958). Federation Proceedings 17335.

Wiggans, D. S. \& Johnston, J. M. (1959). Biochimica et Biophysica Acta 32, 69-73. 